\title{
Penerapan Metode Gallery Walk terhadap Berpikir Kreatif dan Komunikasi Matematis Siswa
}

\author{
Nanda Septiyati ${ }^{1}$, Ratih Kusumawati ${ }^{2}$, Lenny Kurniati ${ }^{3}$ \\ 1,2,3 Universitas Ivet \\ *nandaseptiyati97@gmail.com
}

\begin{abstract}
ABSTRAK
Tujuan penelitian ini adalah untuk mengetahui perbedaan kemampuan berpikir kreatif dan komunikasi matematis siswa dengan penerapan metode Gallery Walk dan pembelajaran konvensional, serta meningkatkan kemampuan berpikir kreatif dan komunikasi matematis siswa pada kelompok yang menggunakan metode Gallery Walk. Populasi dalam penelitian ini adalah siswa kelas VIII SMP Negeri 2 Dawe. Sampel yang diambil adalah kelas VIII G sebagai kelas eksperimen dan kelas VIII D sebagai kelas kontrol. Hasil penelitian menunjukan bahwa: (1) ratarata kemampuan berpikir kreatif dan komunikasi matematis siswa pada kelompok yang menggunakan metode Gallery Walk lebih tinggi dari rata-rata nilai yang menggunakan model pembelajaran konvensional; (2) terdapat peningkatan kemampuan berpikir kreatif dan kemampuan komunikasi matematis pada kelompok yang menggunakan metode Gallery Walk.
\end{abstract}

Kata kunci: Gallery Walk, berpikir kreatif, komunikasi matematis.

\section{ABSTRAK}

The purpose of this study was to determine differences in students 'creative thinking abilities and mathematical communication with the application of the Gallery Walk method and conventional learning, as well as improve students' creative thinking and mathematical communication skills in groups using the Gallery Walk method. The population in this study were eighth grade students of SMP Negeri 2 Dawe. The sample taken was class VIII G as the experimental class and class VIII D as the control class. The results showed that: (1) the average ability of creative thinking and mathematical communication of students in groups using the Gallery Walk method was higher than the average value using conventional learning models; (2) there is an increase in the ability to think creatively and mathematical communication skills in groups using the Gallery Walk method.

Keywords: Gallery Walk, creative thinking, mathematical communication. 


\section{PENDAHULUAN}

Berpikir Kreatif menurut Tilaar (2012) merupakan suatu aspek dari eksistensi manusia. Kemampuan untuk mewujudkan eksistensinya itu ialah dengan jalan proses berpikir. Proses berpikir itu dapat berwujud di dalam dua bentuk, yaitu proses berpikir tingkat rendah dan proses berpikir tingkat tinggi. Sedangkan menurut Hendriana (2017) menyatakan bahwa berpikir kreatif matematis merupakan kemampuan matematis esensial yang perlu dikuasai dan dikembangkan oleh siswa yang belajar matematika.

Pada hakikatnya, pengertian berpikir kreatif berhubungan dengan penemuan sesuatu, mengenai hal yang menghasilkan sesuatu yang baru dengan menggunakan sesuatu yang telah ada. Secara tradisional kreativitas dibatasi sebagai mewujudkan sesuatu yang baru dalam kenyataan. Sesuatu yang baru itu mungkin berupa perbuatan atau tingkah laku, suatu bangunan misalnya gedung, dan hasil lainnya.

Berpikir kreatif adalah hasil belajar siswa dalam menggunakan konsep-konsep matematika serta penerapannya yang dapat dilihat dari keasliannya, kelancarannya, kelenturannya, elaborasi, dan evaluasi, serta kemandirian dalam belajarnya Nugrohorini (2014). Kemampuan melihat dari banyak sudut pandang yang mampu memfasilitasi berbagai pihak serta mengkomunikasikannya dengan baik akan menjembatani kepentingan yang beragam dalam kehidupan sosial.

Dalam sudut pandang pendidikan, matematika merupakan bagian yang memiliki peranan penting dalam mengembangkan berbagai kompetensi siswa termasuk berpikir kreatif dan komunikasi matematis. Menurut Wahyuni \& Kurniawan (2018) kemampuan berpikir kreatif merupakan kemampuan yang memberikan ide-ide kepada siswa sesuai dengan kelancaran, keluwesan, keaslian, dan merinci. Kefasihan ditunjukan dengan cepat, keluwesan mengacu pada kemampuan untuk menemukan gagasan yang berbeda-beda dan luar biasa untuk memecahkan suatu masalah.

Tiga komponen yang digunakan untuk menilai kemampuan berpikir kreatif melalui TTCT adalah kefasihan (fluency), fleksibilitas (fleksibility), dan kebaruan (novelty). Dengan pengertian sebagai berikut. a) Kefasihan (fluency) adalah jika siswa mampu menyelesaikan masalah matematika dengan beberapa alternatif jawaban (beragam) dan benar. b) Fleksibilitas (fleksibility) adalah jika siswa mampu menyelesaikan masalah matematika dengan dengan cara yang berbeda. c) Kebaruan (novelty) adalah jika siswa mampu menyelesaikan masalah matematika dengan beberapa jawaban yang berbeda tetapi bernilai benar dan satu jawaban yang tidak biasa dilakukan oleh siswa pada tahap perkembangan mereka atau tingkat pengetahuannya.

Menurut Sardiman sebagaimana dikutip oleh Darkasyi (2014), komunikasi (secara konseptual) yaitu memberitahukan dan menyebarkan berita, pengetahuan, pikiran-pikiran, dan nilai-nilai dengan maksud untuk mengunggah partisipasi agar hal-hal yang diberitahukan menjadi milik bersama. Sedangkan menurut Rois (2013), kemampuan komunikasi matematika merupakan salah satu kemampuan atau kecakapan seseorang dalam menyampaikan informasi atau mengkomunikasikan suau gagasan dan situasi melalui lisan maupun melalui tulisan.

Proses komunikasi membantu siswa membangun makna untuk gagasan-gagasan serta menjadikan gagasan-gagasan tersebut diketahui publik. Adapun indikator kemampuan komunikasi matematis yang digunakan yaitu: a) kemampuan menyatakan, mengekspresikan, 
dan melukiskan ide-ide matematika ke dalam bentuk gambar atau model matematika lain, b) kemampuan menyatakan situasi, gambar, diagram, atau benda nyata kedalam bahasa, simbol, ide atau model matematika, c) kemampuan dalam menggunakan istilah-istilah, notasi-notasi matematika dan struktur-strukturnya untuk menyajikan ide, d) kemampuan menyusun argumen secara tertulis dalam menyelesaikan suatu masalah matematis.

Nurhayati (2013) menyatakan bahwa kurang berhasilnya siswa dalam pembelajaran matematika, disebabkan proses pembelajaran yang diselenggarakan selama ini kurang melibatkan partisipasi aktif siswa, sehingga siswa pasif dan hanya menerima informasi dari guru. Selain dari faktor siswa itu sendiri, metode pembelajaran yang digunakan guru kurang tepat, dan cenderung menggunakan pembelajaran konvensional. Pembelajaran konvensional yang masih banyak dijumpai kurang melibatkan siswa secara aktif, siswa cenderung pasif dalam proses pembelajaran karena proses pembelajaran berpusat kepada guru, siswa hanya mendengarkan dan mencatat materi dari penyampaian guru. Proses pembelajaran, siswa dikatakan aktif jika terjadinya interaksi, misalnya interaksi yang terjadi antara guru dan siswa, atau antarsiswa itu sendiri.

Berdasarkan studi literatur yang telah dilakukan Gallery Walk memiliki peluang untuk mengatasi hal tersebut. Gallery Walk juga dapat mendorong berpikir kreatif siswa dalam belajar matematika. Karena dalam metode pembelajaran Gallery Walk siswa dituntut untuk mencari informasi, mengolah masalah, dan menyajikannya dalam suatu karya visual serta dapat menjelaskannya pada siswa lain sehingga dibutuhkan komunikasi matematis untuk memperoleh tujuan tersebut.

Model Gallery Walk merupakan model pembelajaran kunjungan karya terhadap kelompok lain, kelompok yang mengunjungi karya kelompok tersebut harus dapat memberi saran, komentar, masukan, bahkan penambahan. Sedangkan kelompok yang menjaga karya harus mampu menanggapi apa yang dipertanyakan oleh kelompok penanya. Aktivitas ini merupakan cara untuk menilai dan merayakan apa yang telah peserta didik pelajari setelah rangkaian pembelajaran studi Silberman (2010).

Gufron (2011) menguraikan bahwa secara etimologi Gallery Walk terdiri dari dua kata, yaitu Gallery dan Walk. Gallery adalah pameran. Pameran merupakan kegiatan untuk memperkenalkan produk, karya atau gagasan kepada khalayak ramai. Misalnya pameran buku, tulisan, lukisan, dan sebagainya. Sedangkan Walk artinya berjalan, melangkah. Salah satu metode pembelajaran yang digunakan adalah metode Gallery Walk.

Gallery Walk merupakan suatu metode pembelajaran yang mampu mengakibatkan daya emosional siswa untuk menemukan pengetahuan baru dan dapat mempermudah daya ingat jika sesuatu yang ditemukan itu dilihat secara langsung. Gallery Walk juga mendorong siswa untuk dapat mengomunikasikan gagasan dengan simbol, tabel, diagram, suatu karya visual yang menarik atau media lain untuk memperjelas keadaan atau masalah agar pembelajaran lebih menarik dan membantu siswa dalam memahami materi pembelajaran.

Berdasarkan beberapa penjelasan di atas mengenai kurangnya kemampuan berpikir kreatif dan komunikasi matematis siswa pada pembelajaran matematika maka akan dilakukan pembelajaran menggunakan metode Gallery Walk yang diharapkan dapat meningkatkan kemampuan berpikir kreatif dan komunikasi matematis siswa sehingga siswa yang kesulitan mengkomunikasikan gagasan, ide dan merubah masalah kedalam notasi, simbol dan bahasa matematika dapat terselesaikan. 


\section{METODE}

Penelitian ini menggunakan pendekatan kuantitatif, yang menekankan analisisnya pada data-data yang diolah dengan metode statistika penelitian kuantitatif. Penelitian ini dilakukan pada bulan juli 2019, populasi dalam penelitian ini adalah siswa kelas VIII SMP Negeri 2 Dawe berjumlah 218 siswa. Pengambilan sampel dilakukan menggunakan purposive sampling, yaitu kelas yang kemampuan berpikir kreatif dan komunikasi matematisnya rendah. Sampel yang digunakan adalah kelas VIII G sebagai kelas eksperimen yang diajak menggunakan metode Gallery Walk dan kelas VIII D sebagai kelas kontrol yang diajar menggunakan metode konvensional.

\subsection{Prosedur Penelitian}

Sebelum peneliti melaksanakan penelitian, peneliti membuat instrumen penelitian kemudian divalidasikan ke validator I dan validator II. Setelah instrumen divalidasi, peneliti melakukan uji coba instrumen di kelas uji coba kemudian peneliti siap melaksanakan penelitian. Hasil uji coba kemudian dilakukan pengujian validitas, reliabilitas, daya pembeda, dan tingkat kesukaran. Penelitian yang dilakukan peneliti yaitu proses pertama peneliti mengajar secara konvensional di kelas kontrol. Peneliti menggunakan metode Gallery Walk dalam mengajar di kelas eksperimen. Pengukuran kemampuan berpikir kreatif dan komunikasi matematis siswa menggunakan soal pretest dan posttest. Soal pretest diberikan saat pertama kali pertemuan dan soal posttest diberikan pada saat akhir pembelajaran.

Sebelum melakukan analisis uji kesamaan dua rata-rata dan uji gain terhadap data nilai, perlu dilakukan uji prasyarat terlebih dahulu, yaitu uji normalitas dan uji homogenitas data. Apabila data berdistribusi normal, maka pengujian hipotesis dilakukan dengan statistik parametrik, tetapi apabila data berdistribusi tidak normal, maka pengujian hipotesis dilakukan dengan menggunakan statistika non parametrik. Hasil yang sudah dilakukan uji normalitasdan homogenitas kemudia dilakukan uji perbedaan rata-rata dan uji gain.

\subsection{Desain Penelitian}

Fase pertama peneliti melakukan orientasi peserta didik kepada masalah yaitu memahami bagaimana sistem persamaan linier dua variabel. Fase kedua peneliti mengorganisasikan peserta didik dengan membagi siswa dalam beberapa kelompok dan setiap kelompok menyelesaikan tugas dan ditulis semenarik mungkin pada kertas karton. Fase ketiga peneliti membimbing penyelidikan individu dan kelompok yaitu menjadi fasilitator untuk jalannya interaksi diantara peserta didik yang mengalami kesulitan dan memberikan bimbingan. Fase keempat peneliti mengembangkan dan menyajikan hasil karya yaitu menempel hasil kerja pada dinding tembok dan setiap kelompok menjaga dan menjelaskan hasil dari diskusi tersebut lalu berjalan bergantian dari mengunjungi setiap kelompok. Fase kelima peneliti menganalisa dan mengevaluasi proses pemecahan masalah yaitu menegaskan kembali jawaban yang benar dan memandu untuk membuat kesimpulan mengenai sistem persamaan linier dua variabel dan siswa diberi soal tes untuk dikerjakan secara individu dan dikumpulkan sebagai umpan balik pembelajaran yang telah dilaksanakan. 


\section{HASIL DAN PEMBAHASAN}

Hasil uji coba melalui validasi soal diperoleh bahwa soal sebanyak 8 butir menyatakan 5 soal berkriteria valid dan 3 soal berkriteria tidak valid, jadi 5 soal tersebut digunakan untuk penelitian dan 3 soal tersebut tidak digunakan. Kemudian di kelas eksperimen dan kelas kontrol diberikan soal pretest dan akan diuji normalitas dan homogenitasnya. Maka dari hasil uji normalitas diperoleh nilai pada kelas eksperimen 0,119 untuk kemapuan berpikir kreatif dan 0,076 untuk kemampuan komunikasi matematis sedangkan pada kelas kontrol 0,117 pada kemampuan berpikir kreatif dan 0,062 pada kemampuan komunikasi matematis, jadi hasil data teresbut berdistribusi normal karena $>0,05$. Setelah dilakukan uji normalitas kemudian dilakukan uji homogenitas diperoleh 0,673 pada kemampuan berpikir kreatif dan 0,376 pada kemampuan komunikasi matematis, jadi data tersebut memiliki varians yang homogen karena 0,673 dan $0,376>0,05$. Selanjutnya akan dilakukan uji perbedaan rata-rata pada kemampuan berpikir kreatif dan komunikasi matematis lalu dilanjutkan uji gain.

Pada uji perbedaan rata-rata maka peneliti menyimpulkan bahwa rata-rata kemampuan berpikir kreatif siswa yang memperoleh pembelajaran matematika mengggunakan metode Gallery Walk lebih dari rata-rata kemampuan berpikir kreatif siswa yang memperoleh pembelajaran matematika menggunakan model pembelajaran Konvensional dengan alasan Sig $(2$-tailed $)=(0,010)<0,05$. Hasil uji t dapat dilihat pada Tabel 3.1 .

Tabel 3.1. Hasil Uji t Berpikir Kreatif

\begin{tabular}{|c|c|c|c|c|c|c|c|c|c|c|}
\hline & & $\begin{array}{c}\text { Leven } \\
\text { for } \mathrm{Eq} \\
\text { Var }\end{array}$ & $\begin{array}{l}\text { s Test } \\
\text { lity of } \\
\text { nces }\end{array}$ & \multirow{3}{*}{$\mathrm{T}$} & \multirow{3}{*}{$\mathrm{df}$} & \multirow{3}{*}{$\begin{array}{l}\text { Sig. (2- } \\
\text { tailed) }\end{array}$} & \multirow{3}{*}{$\begin{array}{c}\text { Mean } \\
\text { Difference }\end{array}$} & \multirow{3}{*}{$\begin{array}{l}\text { Std. Error } \\
\text { Difference }\end{array}$} & \multirow{2}{*}{\multicolumn{2}{|c|}{$\begin{array}{c}5 \% \text { Confidence } \\
\text { Interval of the } \\
\text { Difference }\end{array}$}} \\
\hline & & \multirow[t]{2}{*}{$\mathrm{F}$} & \multirow[t]{2}{*}{ Sig. } & & & & & & & \\
\hline & & & & & & & & & Lower & Upper \\
\hline \multirow{2}{*}{ NGAIN PERSEN } & $\begin{array}{l}\text { Equal } \\
\text { variances } \\
\text { assumed }\end{array}$ & .724 & .399 & 2.673 & 56 & .010 & 7.745 & 2.898 & 7.563 & 7.928 \\
\hline & $\begin{array}{l}\text { Equal } \\
\text { variances not } \\
\text { assumed }\end{array}$ & & & 2.673 & 54.294 & .010 & 7.745 & 2.898 & 7.563 & 7.928 \\
\hline
\end{tabular}

Pada uji perbedaan rata-rata maka peneliti menyimpulkan bahwa rata-rata kemampuan komunikasi matematis siswa yang memperoleh pembelajaran matematika mengggunakan metode Gallery Walk tidak sama dengan atau lebih dari rata-rata kemampuan komunikasi matematis siswa yang memperoleh pembelajaran matematika menggunakan model pembelajaran Konvensional dengan alasan Sig $(2$-tailed $)=(0,010)<0,05$. Hasil uji t dapat dilihat pada Tabel 3.2. 
Tabel 3.2. Hasil Uji t Komunikasi Matematis

Independent Samples Test

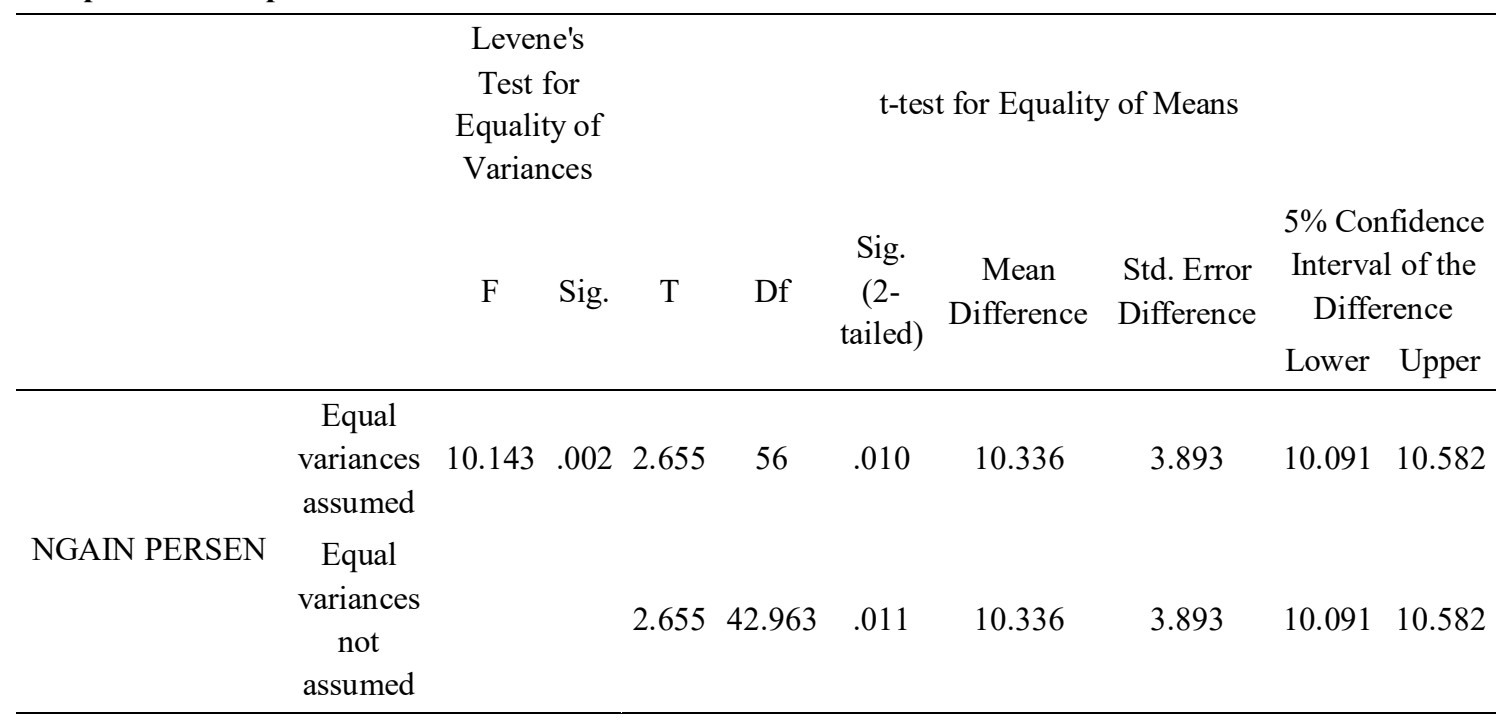

Selanjutnya akan dilakukan uji gain untuk mengetahui taraf signifikansi peningkatan berpikir kreatif dan komunikasi matematis siswa antara sebelum dan sesudah diberi perlakuan. Tabel 3.3 adalah tabel indeks kriteria presentase gain.

Tabel 3. Indeks kriteria presentase gain

\begin{tabular}{cl}
\hline Presentase $(\%)$ & Tafsiran \\
\hline$<40$ & Tidak Efektif \\
$40-55$ & Kurang Efektif \\
$56-75$ & Cukup Efektif \\
$>76$ & Efektif \\
\hline
\end{tabular}

Rata-rata indeks gain yang diperoleh siswa kelas eksperimen kemampuan berpikir kreatif sebesar 61,32 artinya mempunyai peningkata yang tergolong cukup efektif sedangkan pada kemampuan komunikasi matematis diperoleh rata-rata sebesar 72,31 yang tergolong cukup efektif. Pada siswa kelas kontrol kemampuan berpikir kreatif sebesar 53,58 artinya mempunyai peningkatan yang tergolong kurang efektif sedangkan pada komunikasi matematis sebesar 61,69 yang tergolong cukup efektif.

Nilai rata-rata indeks gain eksperimen lebih tinggi daripada rata-rata indeks gain kelas kontrol. Dengan demikian dapat disimpulkan bahwa peningkatan kemampuan berpikir kreatif dan komunikasi matematis kelas eksperimen yang menggunakan metode Gallery Walk lebih tinggi daripada kelas kontrol.

Dari data peneliti yang sudah dianalisis, didapatkan hasil sebagai berikut. 1) Pada uji perbedaan rata-rata berpikir kreatif didapatkan hasil untuk kelas eksperimen yang menggunakan metode Gallery Walk lebih tinggi dari pada kelas kontrol yang menggunakan metode pembelajaran konvensional. Hal ini dibuktikan dengan hasil perhitungan menggunakan aplikasi SPSS 16 yang menunjukkan nilai sig(2-tailed) 0,011, dimana 0,011<0,05 maka $\mathrm{H}_{0}$ 
ditolak yaitu rata rata pada kemampuan berpikir kreatif siswa kelas eksperimen lebih tinggi dari rata-rata kemampuan berpikir kreatif siswa kelas kontrol. Hal ini sejalan dengan penelitian Utami (2014) menyatakan bahwa aktivitas yang ditimbulkan model pembelajaran problem solving berbasik Gallery Walk mempengaruhi pemecahan masalah siswa sebesar $80 \%$.

Pada uji perbedaan rata-rata komunikasi matematis didapatkan hasil untuk kelas eksperimen yang menggunakan metode Gallery Walk lebih tinggi dari pada kelas kontrol yang menggunakan metode pembelajaran konvensional. Hal ini dibuktikan dengan hasil perhitungan menggunakan aplikasi SPSS 16 yang menunjukkan nilai sig(2-tailed) 0,010, dimana 0,010 < 0,05 maka $\mathrm{H}_{0}$ ditolak yaitu rata rata pada kemampuan komunikasi matematis siswa kelas eksperimen lebih tinggi dari rata-rata kemampuan komunikasi matematis siswa kelas kontrol. Hal ini sependapat dengan Putra \& Nuraida (2018) menyatakan bahwa kelompok kelas eksperimen yang menggunakan metode Gallery Walk mengalami peningkatan komunikasi matematis.

Pada uji n-gain berpikir kreatif didapatkan peningkatan yang cukup efektif, rata-rata nilai dari kelas eksperimen lebih tinggi dari kelas kontrol. Hal ini dibuktikan dengan hasil perhitungan menggunakan aplikasi SPSS 16 yang menunjukan mean dari kelas ekperimen 61,32 dan kelas kontrol 53,58. Hal ini sependapat dengan penelitian Wahyuni \& Kurniawan (2018) menyatakan bahwa kemampuan berpikir kreatif mempengaruhi hasil belajar siswa.

Pada uji n-gain komunikasi matematis didapatkan peningkatan yang cukup efektif, ratarata nilai dari kelas eksperimen lebih tinggi dari kelas kontrol. Hal ini dibuktikan dengan hasil perhitungan menggunakan aplikasi SPSS 16 yang menunjukan mean dari kelas ekperimen 72,31 dan kelas kontrol 61,98. Sejalan dengan penelitian Purwasih (2015) bahwa terdapat peningkatan kemampuan komunikasi matematis antara siswa yang mendapatkan pembelajaran matematika dengan menggunakan pembelajaran model inquiri termbimbing lebih baik dari pada pembelajaran konvensional.

Hasil penelitian ini menunjukan bahwa pembelajaran matematika dengan metode Gallery Walk mampu meningkatkan kemampuan berpikir kreatif dan komunikasi matemtis siswa dari pada pembelajaran matematika menggunakan konvensional. Pengaruh yang timbul dalam pembelajaran menggunakan metode Gallery Walk bahwa siswa mampu memahami konsepkonsep dengan cara menyelesaikan suatu permasalahan, siswa mampu mengembangkan cara berpikirnya, siswa aktif dalam pembelajaran, siswa mampu mengemukakan pendapatpendapatnya, siswa berusaha mencari jawaban yang lain serta menjadi aktif dalam pembelajaran.

Dapat disimpulkan bawa pembelajaran menggunakan metode Gallery Walk lebih baik dibandingkan dengan pembelajaran konvensional. Dengan adanya metode Gallery Walk, siswa dituntut untuk membuat suatu daftar baik berupa gambar maupun skema sesuai hal-hal apa yang ditemukan atau diperoleh pada saat diskusi kelompok, terjadi sinergi saling menguatkan pemahaman terhadap tujuan pembelajaran, mengaktifkan fisik dan mental siswa dan membiasakan siswa memberi dan menerima kritik.

\section{SIMPULAN}

Simpulan dari penelitian ini adalah (1) rata-rata hasil belajar siswa pada kelompok eksperimen dengan kemampuan berpikir kreatif lebih dari rata-rata hasil belajar siswa pada 
kelompok yang menggunakan pembelajaran konvensional, (2) rata-rata hasil belajar siswa pada kelompok eksperimen dengan kemampuan komunikasi matematis lebih dari rata-rata hasil belajar siswa pada kelompok yang menggunakan pembelajaran konvensional, (3) penerapan metode Gallery Walk dapat meningkatkan kemampuan berpikir kreatif, (4) penerapan metode Gallery Walk dapat meningkatkan kemampuan komunikasi matematis.

Saran dari penelitian ini adalah (1) ketika menerapkan metode Gallery Walk, pemilihan soal-soal pemecahan masalah dalam kehidupan sehari-hari perlu diperhatikan, (2) persiapan pembelajaran, pengelolaan waktu, dan pengelolaan kelas harus diperhatikan pada saat pelaksanaan pembelajaran dengan metode Gallery Walk, (3) penerapan metode Gallery Walk sebaiknya disesuaikan terlebih dahulu dengan materi yang diajarkan.

\section{DAFTAR PUSTAKA}

Darkasyi, M. dkk. (2014). Peningkatan Kemampuan Komunikasi Matematis dan Motivasi Siswa dengan Pembelajaran Pendekatan Quantum Learning pada Siswa SMP Negeri 5 Lhokseumawe. Jurnal Didaktik Matematika.

Hendriana,H., Rohaeti, E. E., \& Sumarmo, U. (2017). HardSkill dan Soft Skill Matematik Siswa. Bandung: Refika Aditama.

Nugrohorini. S.G. (2014). Meningkatkan Kemampuan Berpikir Kreatif Matematis dan Kemandirian Belajar Siswa SMP melalui Pembelajaran tidak Langsung dengan Resitasi. Thesis. Universitas Pendidikan Indonesia

Nurhayati, R.M. (2013). Meningkatkan Keaktifan dan Hasil Belajar Matematika pada Penjumlahan Pecahan Menggunakan Pendekatan PAIKEM Siswa Kelas V SDN 228. Artikel Ilmiah.

Purwasih, R. (2015). Peningkatan Kemampuan Pemahaman Matematis dan Self Confidence Siswa MTS di Kota Cimahi Melalui Model Pembelajaran Inkuiri Terbimbing. Didaktik, 9(1), 16-25.

Putra, R.M., Nuraida, N., \& Srimulyati, S. (2018). Implementasi Model Pembelajaran GalleryWalk Terhadap Kemampuan Komunikasi Matematis Siswa Pada Materi Sistem Persamaan Linier Dua Variabel di Kelas X SMK Negeri 2 Langsa. Al-Kindi: Jurnal Ilmiah Mahasiswa Pendidikan Matematika (JIMPMA), 1(1), 1-7.

Rois, U. R. (2013). Kemampuan Komunikasi Matematis Siswa pada Materi Kubus dan Balok. Skripsi S-1. Universitas Negeri Gorontalo.

Silberman, Melvin L. (2010). Active Learning 101 Cara Belajar Siswa Aktif. Bandung: Nusamedia dan Nuansa.

Utami, W. N., Waluya, S. B., \& Mashuri, M. 2014. Keefektifan Model Pembelajaran Problem Solving Berbasis Gallery Walk Terhadap Kemampuan Pemecahan Masalah. Unnes Journal of Mathematics Education. Universitas Negeri Semarang. 
Wahyuni, A., \& Kurniawan, P. (2018) . Hubungan kemampuan berpikir kreatif terhadap hasil belajar mahasiswa. Matematika, 17(2).

Tilaar, H.A.R. 2012. Pengembangan Kreativitas dan Enterpreneurship. Jakarta: PT Kompas Media Nusantara. 